\title{
Use of Technical Analysis Tools in Nepalese Stock Market
}

\author{
Rashesh Vaidya'
}

\begin{abstract}
This paper has attempted to find the interest of Nepalese investors, brokers and depository participants on the use the technical tools for the analysis of the stock market. The use of technical analysis in context to Nepal shows that the participants in the Nepalese stock market are highly interested on the use of new Hi-Lo price while making their investment decisions. Another interest was seen for trade volume indicators. The Nepalese stock market participants are not seen interested in using the resistance and support level followed by the pattern i.e. candlestick charts while analyzing the stock market trend.
\end{abstract}

Key Words: Technical Analysis, Nepalese Stock Market

\section{INTRODUCTION AND OBJECTIVE}

Technical analysis includes a variety of forecasting techniques such as chart analysis, pattern recognition analysis, seasonality and cycle analysis, and computerized technical trading systems. However, academic research on technical analysis is generally limited to techniques that can be expressed in mathematical forms, namely technical trading systems, although some recent studies attempt to test visual chart patterns using pattern recognition algorithms. A technical trading system consists of a set of trading rules that result from parameterizations, and each trading rule generates trading signals (long, short, or out of market) according to their parameter values (Park and Irwin, 2004).

Since Charles H. Dow first introduced the Dow Theory in the late 1800 s, technical analysis has been extensively used among market participants such as brokers, dealers, fund managers, speculators, and individual investors in the financial industry. In Asia, the history of technical analysis dates back to at least the 18th century when the Japanese developed a form of technical analysis known as candlestick charting techniques. This technique was not introduced to the West until the 1970s (Nison 1991).

1. Lecturer at Siddhartha Vanasthali College of Management. He can be reached at vaidyarashesh@gmail.com 
Technical analysis is the study of past price movements with the goal to predict future price movements from the past. In the book, "The Stock Market Barometer" (1922) William Peter Hamilton laid the foundation of the Dow Theory, the first theory of chart readers. The theory is based on editorials of Charles $\mathrm{H}$. Dow when he was editor of the Wall Street Journal in the period 1889-1902. Robert Rhea popularized the idea in his 1930s market letters and his book "The Dow Theory" (1932). The philosophy underlying technical analysis can already for most part be found in this early work, developed after Dow's death in 1902. Charles Dow thought that expectations for the national economy were translated into market orders that caused stocks to rise or fall in prices over the long term together, usually in advance of actual economic developments. He believed that fundamental economic variables determine prices in the long run. To quantify his theory Charles Dow began to compute averages to measure market movements. This led to the existence of the Dow-Jones Industrial Average (DJIA) in May 1896 and the DowJones Railroad Average (DJRA) in September 1896. The Dow Theory assumes that all information is discounted in the averages; hence no other information is needed to make trading decisions. Further the theory makes use of Charles Dow's notion that there are three types of market movements: primary (also called major), secondary (also called intermediate) and tertiary (also called minor) upward and downward price movements, also called trends. It is the aim of the theory to detect the primary trend changes in an early stage. Minor trends tend to be much more influenced by random news events than the secondary and primary trends and are said to be therefore more difficult to identify. According to the Dow Theory bull and bear markets, that is primary upward and downward trends, are divisible in stages which reflect the moods of the investors (Griffioen, 2003).

James (1968) is one of the first who tests moving-average trading strategies, that is, signals are generated by a crossing of the price through a moving average of past prices. He found no superior performance for these rules when applied to end of month data of stocks traded at the NYSE in the period 1926 to 1960. Numerous surveys indicate that practitioners attribute a significant role to technical analysis. Futures fund managers rely heavily on computer-guided technical trading systems (Irwin and Brorsen 1987; Brorsen and Irwin 1987; Billingsley and Chance 1996), and about $30 \%$ to $40 \%$ of foreign exchange traders around the world believe that technical analysis is the major factor determining exchange rates in the short-run up to six months (Menkhoff 1997; Cheung \& Wong 2000; Cheung, Chinn, \& Marsh 2000; Cheung \& Chinn 2001).

In contrast to the views of many practitioners, most academics are skeptical about technical analysis. Rather, they tend to believe that markets are informationally efficient and hence all available information is impounded in current prices (Fama 1970). Since Donchian (1960), numerous empirical studies have tested the profitability of technical trading rules in a variety of markets for the purpose of either uncovering profitable trading rules or testing market efficiency, or both. Most studies have concentrated on stock markets, both in the US and outside the US, and foreign exchange markets, while a smaller number of studies have analyzed futures markets. Before the mid-1980s, the majority of the technical trading studies simulated only one or two trading systems. In these studies, 
although transaction costs were deducted to compute net returns of technical trading strategies, risk was not adequately handled, statistical tests of trading profits and data snooping problems were often disregarded, and out-of-sample verification along with parameter (trading rule) optimization were not considered in the testing procedure.

After the mid-1980s, however, technical trading studies greatly improved upon the drawbacks of early studies and typically included some of the following features in their testing procedures: (1) the number of trading systems tested increased relative to early studies; (2) returns were adjusted for transaction costs and risk; (3) parameter (trading rule) optimization and the out-of-sample verification were conducted; and (4) statistical tests were performed with either conventional statistical tests or more sophisticated bootstrap methods, or both (Park \& Irwin, 2004).

Although the vast majority of the professional traders use technical analysis, most academics, until recently, had not recognized the validity of these methods. They prefer the much more theoretical fundamental analysis. However, since the article of Brock, Lakonishok and LeBaron (1992), showing that simple forms of technical analysis contain significant predictive power for US equity index returns, many studies in the finance literature have investigated technical analysis to determine its validity as an investment tool. Among others, based on the same universe of 26 trading rules, however, Bessembinder and Chan (1995) argued that although the technical trading rules do have predictive ability in US data, their use would not allow investors to make excess returns in the presence of costly trading.

In contrast to fundamental analysis, which was quick to be adopted by the scholars of modern quantitative finance, technical analysis has been an orphan from the very start. It has been argued that the difference between fundamental analysis and technical analysis is not unlike the difference between astronomy and astrology. Among some circles, technical analysis is known as "voodoo finance". It was found that over the 31year sample period, several technical indicators do provide incremental information and may have some practical value (Lo et al., 2000).

In the backdrop of foregoing background, the objective of the study is to find the preference of investors, brokers and depository participants about the use the technical tools for the analysis of the stock market in Nepal.

\section{REVIEW OF LITERATURE}

Treynor and Ferguson (1985) established the first theoretical model to apply technical analysis and model described that investors choose strategies to hold a security for a particular time period either long or short in order to get benefit from it later after they receive private information at particular point of time. The model concluded that this private information is helpful only with the combination of some additional or further information.

Brown and Jennings (1989) in the article on outperformance of technical analysis said that portfolio strategies works so well when the market does not contain all relevant 
information and there are only few investors who are well aware of that information.

Brock, Lakonishok and LeBaron (1992) explored moving averages and support and resistance levels in order to find out generation of signals for the long and short time period and then to check high and low hits of prices. They argued that we cannot allow to leave those false patterns which are not covered by technical analysis tools and techniques because it is very difficult to enquire too much about data but we can be able to reduce this problem either by providing full reporting of techniques used or by using a very long data and information.

Vasiliou et al. (2004) study shows that Moving Average and Moving Average Convergence Divergence (MACD) can be useful and rewarding in generating better return from the stock market as well.

Menkhoff (2010) analyzed survey evidence from 692 fund managers in five countries, the vast majority of whom rely on technical analysis. At a forecasting horizon of weeks, technical analysis is the most important form of analysis and up to this horizon it is thus more important than fundamental analysis. Technicians are as experienced, as educated, as successful in their career and largely just as overconfident in decisionmaking as others. However, technical analysis is somewhat more popular in smaller asset management firms. What he found most significant is the relation of technical analysis with the view that prices are heavily determined by psychological influences. Consequently, technicians apply trend-following behavior.

Venkatesh and Tyagi (2011) conducted the research on the major Indian stock markets results show that when the market is bullish, participants rely more upon technical analysis and when the market is bearish it is the other way round the participants rely upon the fundamental analysis

Preethi and Santhi (2012) conducted the survey on use of recent techniques such as Neural Network, Data Mining, Markov Model and Neuro-Fuzzy system in Indian stock market offer useful tools for forecasting noisy environments like stock market.

Boobalan (2014) found that on the basis of the knowledge of technical analysis one can predict the perfect investment decision of the stock market. By using the technical indicators the future market of securities would be known in which to invest. The more accurate prediction of stock prices of selected companies the investor to carry out fundamental analysis of stock prices, they can predict of future trend of stock prices.

\section{DATA AND METHODOLOGY}

For collecting primary data, a closed-end questionnaire was designed covering different types of technical analysis tools as used in the questionnaire of Venkatesh and Tyagi (2011) and Menkhoff (2010). The questionnaire was prepared both in English and Nepali language in 5-point Likert scale.

The sample consisted of 710 investors drawn from a population of approximately 700,000 investors having Beneficiary Owners Account with institutions licensed to operate 
demat account. The investors were contacted and requested to fill in the questionnaire by visiting licensed brokerage office during the period November 2016.

Similarly, all 50 brokerage firms of the Nepal Stock Exchange Limited and 60 Depository Participants (DPs) operating during the study period were also considered as the population for the study. Of the 50 brokers firms, 29 firms and of the 60 DPs, only 11 DPs filled-in the questionnaires.

For validity of the study, initially the structured questionnaire was set after through study of the technical analysis related literature particularly by Venkatesh and Tyagi (2011) and Menkhoff (2010). This confirms criterion validity as it measures to correlate with other standard measures of similar constructs or established criteria. This helps to fulfill the construct validity of the instrument to be used in research. Further, a pilot survey was conducted among 150 respondents and the questionnaire was reviewed for validity. But none of the items had to be dropped.

Cronbach's Alpha was calculated to measure internal consistency. Cronbach's Alpha $(\alpha=0.677)$ also attests reliability of the used questionnaire.

\section{DATA ANALYSIS AND INTERPETATION}

\section{Designation of Respondents}

Table 1 shows the designations of the respondents and the percent they covered respectively:

Table 1: Designation of Respondents

\begin{tabular}{cccc}
\hline Designation & Frequency & Percent & Cumulative Percent \\
\hline Investor & 710 & 94.7 & 94.7 \\
Broker & 29 & 3.8 & 98.5 \\
Depository Participant & 11 & 1.5 & 100.0 \\
\hline Total & $\mathbf{7 5 0}$ & $\mathbf{1 0 0 . 0}$ & \\
\hline
\end{tabular}

Source: Field Survey, 2016

Of the total respondents, majority (94.7 percent) of them are active investors (those who actively traded in the securities listed in Nepse).The rest are brokers (3.8 percent) followed by ( 1.5 percent) of the total respondents.

\section{Respondents Profile}

Of the total respondents, 56 percent had an experience in a stock market from one to five years. After this, 15.7 percent had experience of five to 10 years; and 2.3 percent had an experience 20 years and above.

As regards the qualification of the respondents, majority (41.1 percent) of them were 
60 I PYC Nepal Journal of Management, August 2018, Vol. XI, No. 1

with masters degree followed by bachelor degree with 40.5 percent. Just 1.1 percent of the respondents had qualification below School Leaving Certificate (SLC).

Table 2 shows the detail profile of the respondents:

Table 2 : Respondents Profile

\begin{tabular}{|c|c|c|c|c|c|c|c|c|}
\hline $\begin{array}{c}\text { Professional } \\
\text { Experience }\end{array}$ & Frequency & Percent & Qualification & Frequency & Percent & $\begin{array}{c}\text { Age } \\
\text { Group }\end{array}$ & Frequency & Percent \\
\hline Below 1 year & 96 & 12.8 & Below S.L.C. & 8 & 1.1 & $16-30$ & 219 & 29.2 \\
\hline $1-5$ & 420 & 56.0 & S.L.C. & 45 & 6.0 & $30-40$ & 250 & 33.3 \\
\hline $5-10$ & 118 & 15.7 & $\begin{array}{c}\text { Intermediate/ } \\
\text { Plus } 2\end{array}$ & 85 & 11.3 & $40-50$ & 169 & 22.5 \\
\hline $10-20$ & 73 & 9.7 & Bachelor & 304 & 40.5 & $50-60$ & 91 & 12.1 \\
\hline $15-20$ & 26 & 3.5 & Master & 308 & 41.1 & $\begin{array}{l}60 \text { and } \\
\text { above }\end{array}$ & 21 & 2.8 \\
\hline 20 and above & 17 & 2.3 & & & & Total & 750 & 100.0 \\
\hline
\end{tabular}

Source: Field Survey, 2016

Age-wise, majority (33.3 percent) of the respondents were from the age group of 30 to 40 years. The least number were seen from the age group of 60 years and above covering 2.8 percent of the total respondents.

\section{Summary Statistics of the Likert Scale on Uses of Technical Analysis Tools}

Table 3 summarizes the results of the 5-point Likert scale questionnaire:

Table 3 : Summary Statistics of the Likert Scale

\begin{tabular}{lcccccc}
\hline \multicolumn{1}{c}{ Likert Items } & Mean $^{*}$ & $\begin{array}{c}\text { Std. } \\
\text { Deviation }\end{array}$ & Skewness & S.E. & Kurtosis & S.E. \\
\hline Use of new Hi-Lo price & 1.98 & 1.19 & 0.97 & 0.09 & -0.17 & 0.18 \\
Use of trade volume indicators & 2.03 & 1.21 & 0.97 & 0.09 & -0.07 & 0.18 \\
Use of price leading-lagging indicators & 2.06 & 1.24 & 0.95 & 0.09 & -0.17 & 0.18 \\
Use of new Hi-Lo index & 2.12 & 1.26 & 0.82 & 0.09 & -0.49 & 0.18 \\
Use of trend line & 2.78 & 1.50 & 0.23 & 0.09 & -1.35 & 0.18 \\
Use of Relative Strength Index (RSI) & 2.89 & 1.44 & 0.17 & 0.09 & -1.28 & 0.18 \\
Use of moving average & 3.05 & 1.39 & 0.05 & 0.09 & -1.21 & 0.18 \\
Use of support and resistance levels & 3.33 & 1.39 & -0.24 & 0.09 & -1.18 & 0.18 \\
Use of pattern i.e. candlestick charts & 3.73 & 1.36 & -0.62 & 0.09 & -0.90 & 0.18 \\
\hline
\end{tabular}

Source: Field Survey, 2016 (*Items listed in ascending order)

The questionnaire stated with ' 1 ' for 'Very High' use and ' 5 ' for 'Very Low' use of the technical tools. Thus, the lowest mean is for the 'Use of new Hi-Lo price' which reflects 
that the respondents are highly interested on the use of new Hi-Lo price while making their decisions in the Nepalese stock market. It is followed by the 'Use of trade volume indicators' with the mean of 2.03. The respondents are not seen interested in using the pattern i.e. candlestick charts while analyzing the stock market trend with the lowest mean of 3.73 only.

Skewness and kurtosis are the basic measures of dispersion. Skewness shows the symmetrical nature of the data set. The results in Table 3 show that the skewness for the 'Use of support and resistance' and 'Use of pattern i.e. candlestick charts' are seen negatively skewed with the value -0.24 and -0.62 respectively. At the same time, kurtosis measures the degree of peakedness or flatness of a distribution as compared to normal distribution. The results at Table 3 show that the distribution is seen platykurtic, i.e., flatness for all the items with the kurtosis value negative.

\section{CONCLUSION AND IMPLICATION}

The use of technical analysis in context to Nepal shows that the investors, brokers and depository participants are highly interested on the use of 'new Hi-Lo price' while making their investment decisions. Another technical tool of interest among Nepalese stock market participants is 'trade volume indicators'. The respondents are not interested in using the 'resistance and support level' followed by the pattern, i.e., 'candlestick charts' while analyzing the stock market trend.

Though the Nepalese stock market is in the growing stage with a short history of about two and half decades, the attraction in the stock market among the Nepalese investors is increasing day-by-day. The main focus of participation in the stock market is for higher return. For that purpose, they are using certain technical analysis tools for their investment decisions. Technical tools generate profit only in inefficient market, which suggests Nepalese market is not efficient.

\section{REFERENCE}

Bessembinder H., \& Chan K. (1995). The profitability of technical trading rules in the Asian stock markets. Pacific-Basin Financial Journal, 3, 257-284.

Billingsley, R., \& Chance, D. M. (1996). Benefits and limitations of diversification among commodity trading advisors. Journal of Portfolio Management, 23(1), 65-80.

Boobalan, C. (2014). Technical analysis in select stocks of Indian companies. International Journal of Business and Administration Research Review, 2(4), 26-36.

Brock, W., Lakonishok J., \& LeBaron, B. (1992). Simple technical trading rules and the stochastic properties of stock returns. The Journal of Finance, 47(5), 1731-1764.

Brorsen, B. W., \& Irwin, S. H. (1987). Futures funds and price volatility. The Review of Futures Markets, 6, 118-135.

Brown, D., \& Jennings, R.(1989). On technical analysis. Review of Financial Studies, 2(4), 527551.

Burns, R. B., \& Burns, R. A. (2008). Business research methods and statistics using SPSS (First ed.). London: SAGE Publications Ltd.

Cheung, Y. W., \& Wong, C. Y. P. (2000). A survey of market practitioners' views on exchange rate dynamics. Journal of International Economics, 51, 401-419. 
Cheung, Y. W., \& Chinn, M. D. (2001). Currency traders and exchange rate dynamics: A survey of the US market. Journal of International Money and Finance, 20, 439-471.

Cheung, Y. W., Chin, M. D., \& Marsh, I. W. (2000). How do UK-based foreign exchange dealers think their market operates? NBER Working Paper (7524).

Donchian, R. D. (1960, November/December). High finance in copper. Financial Analysts Journal, 133-142.

Edwards, R. D., Magee, J., \& Basettii, W. H. C. (2001). Technical analysis of stock trends. (8 ${ }^{\text {th }}$ ed.). CRC Press.

Fama, E. F. (1970). Efficient capital markets: A review of theory and empirical work. The Journal of Finance, 25(2), 383-417.

Griffoen, G. A. (2003). Technical analysis in financial market. Amsterdam: University of Amsterdam.

Hamilton, W. P. (1922). The stock market barometer. New York: John Wiley \& Sons Inc.

Irwin, S., \& Brorsen, B. W. (1987). A note on the factors affecting technical trading system returns. Journal of Futures Markets, 7, 591-595.

James, F. J. (1968). Monthly moving averages-an effective investment tool? Journal of Financial and Quantitative Analysis, 3(3), 315-326.

Lo, A. W., Mamaysky, H., \& Wang, J. (2000). Foundations of technical analysis: Conceptional algorithms, statistical inference, and empirical implementation. Journal of Finance, 55, 17051764.

Menkhoff, L. (1997). Examining the use of technical currency analysis. International Journal of Finance and Economics, 2, 307-318.

Menkhoff, L. (2010). The use of technical analysis by fund managers: International evidence. Journal of Banking and Finance, 34(11), 2573-2586.

Nison, S. (1991). Japanese Candlestick Charting Technique. New York: New York Institute of Finance.

Park, C. H., \& Irwin, S. H. (2004). The profitability of technical analysis: A review. Illinois: AgMAS Project Report.

Preethi, G., \& Santhi, B. (2012). Stock market forecasting techniques: A survey. Journal of Theoretical and Applied Information Technology, 46(1), 24-30.

Pring, M. J. (1980). Technical analysis. Cambridge: Cambridge University.

Rhea, R. (1932). The Dow Theory: An explanation of its development and an attempt to define its usefulness as an aid in speculation. New York: Barron's.

Treynor, J. L., \& Ferguson, R. (1985). In defense of technical analysis. Journal of Finance, 40, 757-773.

Vasiliou, D., Eriotis, N., \& Papathanasiou, S. (2004). How rewarding is technical analysis? Evidence from Athens stock exchange (ASE). Operational Research, 6(2), 85-102.

Venkatesh, C., \& Tyagi, M. (2011). Fundamental analysis as a method of share valuation in comparison with technical analysis. Bangladesh Research Publications Journal, 5(3), 167174.

Venkatesh, C., \& Tyagi, M. (2011). Technical analysis and its usage in Indian capital markets: A survey. Bangladesh Research Publications Journal, 5(4), 282-294.

Zikmund, W. G., Babin, B. J.,Carr, J. C., Adhikari, A., \& Griffin, M. (2012). Business research methods ( $8^{\text {th }}$ ed.). Delhi: CENGAGE Learning. 


\section{Annex-1 A Survey Questionnaire}

\section{Use of Technical Analysis Tools in Nepalese Stock Market}

Age (उमेर):......

Qualification (योग्यता):..........

Professional Experience (कार्यक्षेत्रको अनुभव):......

Designation (कार्यक्षेत्र): Investor/Broker/ Depository Participant

Make a tick-mark $(\sqrt{ })$ on appropriate number as per following scheme for each statement. प्रयोग्रको मात्राका आधारमा $(\sqrt{ })$ चिन्ह उपयुक्त ठाउँमा लगाउन होला ।

Please specify how much you use the following technical tools for analyzing the stock market.

शेयर बजारको त्रिश्लेशण गर्न निम्न प्राविधिक औजार कतिको प्रयोग गर्नु हुन्छ, उल्लेख गर्नुहोस् ।

\begin{tabular}{|l|l|l|l|l|l|l|}
\hline Very High (अति उच्च) & 1 & 2 & 3 & 4 & 5 & Very Low (अति न्यून) \\
\hline
\end{tabular}

Use of patterns i.e. candlestick charts

मैनबत्ति चित्रको प्रयोग

\begin{tabular}{|l|l|l|l|l|l|l|}
\hline Very High & 1 & 2 & 3 & 4 & 5 & Very Low \\
\hline
\end{tabular}

Use of support and resistance levels

टेवा र प्रतिरोध मापनको प्रयोग

\begin{tabular}{|l|l|l|l|l|l|l|}
\hline Very High & 1 & 2 & 3 & 4 & 5 & Very Low \\
\hline
\end{tabular}

Use of moving average

चलयमान औसतको प्रयोग

\begin{tabular}{|l|l|l|l|l|l|l|}
\hline Very High & 1 & 2 & 3 & 4 & 5 & Very Low \\
\hline
\end{tabular}

Use of trend line

रेखा चित्रको प्रयोग

\begin{tabular}{|l|l|l|l|l|l|l|}
\hline Very High & 1 & 2 & 3 & 4 & 5 & Very Low \\
\hline
\end{tabular}

Use of price leading-lagging indicators मुल्य उतार-चढाब सूचांकको प्रयोग

\begin{tabular}{|l|l|l|l|l|l|l|}
\hline Very High & 1 & 2 & 3 & 4 & 5 & Very Low \\
\hline
\end{tabular}


64 I PYC Nepal Journal of Management, August 2018, Vol. XI, No. 1

Use of new Hi-Lo Index

नयाँ उच्च-न्यून सूचांकको प्रयोग

\begin{tabular}{|l|l|l|l|l|l|l|} 
Very High & 1 & 2 & 3 & 4 & 5 & Very Low \\
\hline
\end{tabular}

Use of new Hi-Lo price

नयाँ उच्च-न्यून मुल्यको प्रयोग

\begin{tabular}{|l|l|l|l|l|l|l|}
\hline Very High & 1 & 2 & 3 & 4 & 5 & Very Low \\
\hline
\end{tabular}

Use of relative strength index (RSI) तुलनात्मक मुल्य परिवर्तनको प्रभाब सूचांकको प्रयोग

\begin{tabular}{|l|l|l|l|l|l|l|}
\hline Very High & 1 & 2 & 3 & 4 & 5 & Very Low \\
\hline
\end{tabular}

Use of trade volume indicators कारोवार-मात्रा सूचांकको प्रयोग

\begin{tabular}{|l|l|l|l|l|l|l|}
\hline Very High & 1 & 2 & 3 & 4 & 5 & Very Low \\
\hline
\end{tabular}

Thank You !

धन्यवाद ! 